\title{
Are Two Employment Surveys Better than One?
}

\author{
Kevin L. Kliesen
}

$\mathrm{E}$ conomic analysts and policymakers pay a great deal of attention to employment data. The Bureau of Labor Statistics' monthly employment report is often taken as a key early indicator of aggregate economic activity. Moreover, the National Bureau of Economic Research's business cycle dating committee uses employment to help determine business cycle peaks and troughs. Thus, changes in employment can reflect the economy's evolving strength or weakness over the near-term. (Over longer periods, the change in employment depends more on trend growth of labor productivity and labor force participation rates.)

When using employment to predict near-term economic growth, analysts must choose which employment survey to use. The Bureau of Labor Statistics presents two measures of employment: one from the Current Population Survey (CPS), with about 60,000 households; the other from the Current Employment Statistics (CES), with about 400,000 establishments, which cover about a third of all nonfarm payroll workers. Although the household and establishment measures of employment differ considerably, they tend to show similar growth trends over longer periods of time. ${ }^{1}$

The two series had been moving in two distinct patterns: From January 1994 to March 2001, the establishment survey averaged about 233,000 additional jobs per month, while the household survey averaged only about 184,000 per month. But, since the recession trough in November 2001, the opposite has occurred-household employment has increased more, by an average of about 148,000 per month, while payroll employment has increased by only 82,000 per month.

So, should analysts continue to rely more on the payroll survey or put more weight on the household survey? The table shows simple correlations between the growth of two measures of economic activity - industrial production and real GDP - and three measures of labor input: the CES, the CPS, and the average of the two surveys over three separate periods. The 1994 breakpoint is chosen because the CPS was changed in several important ways; the 2001 break point was chosen because it is the peak of the 1991-2001 expansion.

The table shows that the correlation between employment growth and industrial production is generally stronger than between employment and real GDP. Second, from 1950 to 1993, the correlation between the growth of payroll employment and real output was larger than the correlation between the growth of household employment and output; this is consistent with the

conventional wisdom noted earlier. Third, the correlation between output growth and either measure of employment growth was much weaker during the 1990s, possibly due to the increase in the trend growth of labor productivity and the sharp rise in stock prices.

For the most recent period, the CPS is more highly correlated with industrial production growth (0.77) than is the CES (0.67). An interesting finding is that, since 2001, the correlation between the growth of the combined CES and CPS measure and real GDP is larger than the correlation between the establishment or household measures alone, which is consistent with recent results. ${ }^{2}$ Thus, economic analysts may want to use the average of the payroll and household surveys to measure underlying employment trends and, hence, the trend in near-term real GDP growth.

The change in these correlations might have been caused by the relative growth of self-employment, which is counted in the CPS but not in the CES. From January 1994 to November 2001, self employment fell 1.6 percent. However, since November 2001, self-employment has increased by 9.3 percent to about 9.5 million; meanwhile, total household employment has increased only 6.3 percent. If this trend continues, economic analysts may want to pay closer attention to the household survey.

\footnotetext{
${ }^{1}$ Bowler, Mary and Morisi, Teresa L. "Understanding the Employment Measures from the CPS and CES Survey." Monthly Labor Review, February 2006, pp. 23-38; www.bls.gov/opub/mlr.

2 Perry, George L. "Gauging Employment: Is the Professional Wisdom Wrong." Brookings Papers on Economic Activity, 2005, 2, pp. 285-311.
}

\section{Correlation Between Various Measures of Employment and Output Growth}

\begin{tabular}{lccc} 
& CES & CPS & CES + CPS \\
\hline $\begin{array}{l}\text { 1950:Q1 to 1993:Q4 } \\
\text { Industrial production }\end{array}$ & 0.82 & 0.73 & 0.80 \\
$\quad$ Real GDP & 0.80 & 0.69 & 0.77 \\
1994:Q1 to 2000:Q4 & & & \\
$\quad$ Industrial production & 0.65 & 0.44 & 0.62 \\
$\quad$ Real GDP & 0.34 & 0.41 & 0.45 \\
2001:Q1 to 2006:Q2 & & & \\
$\quad$ Industrial production & 0.67 & 0.77 & 0.74 \\
Real GDP & 0.67 & 0.67 & 0.72
\end{tabular}

NOTE: Growth rates are four-quarter percent changes. 